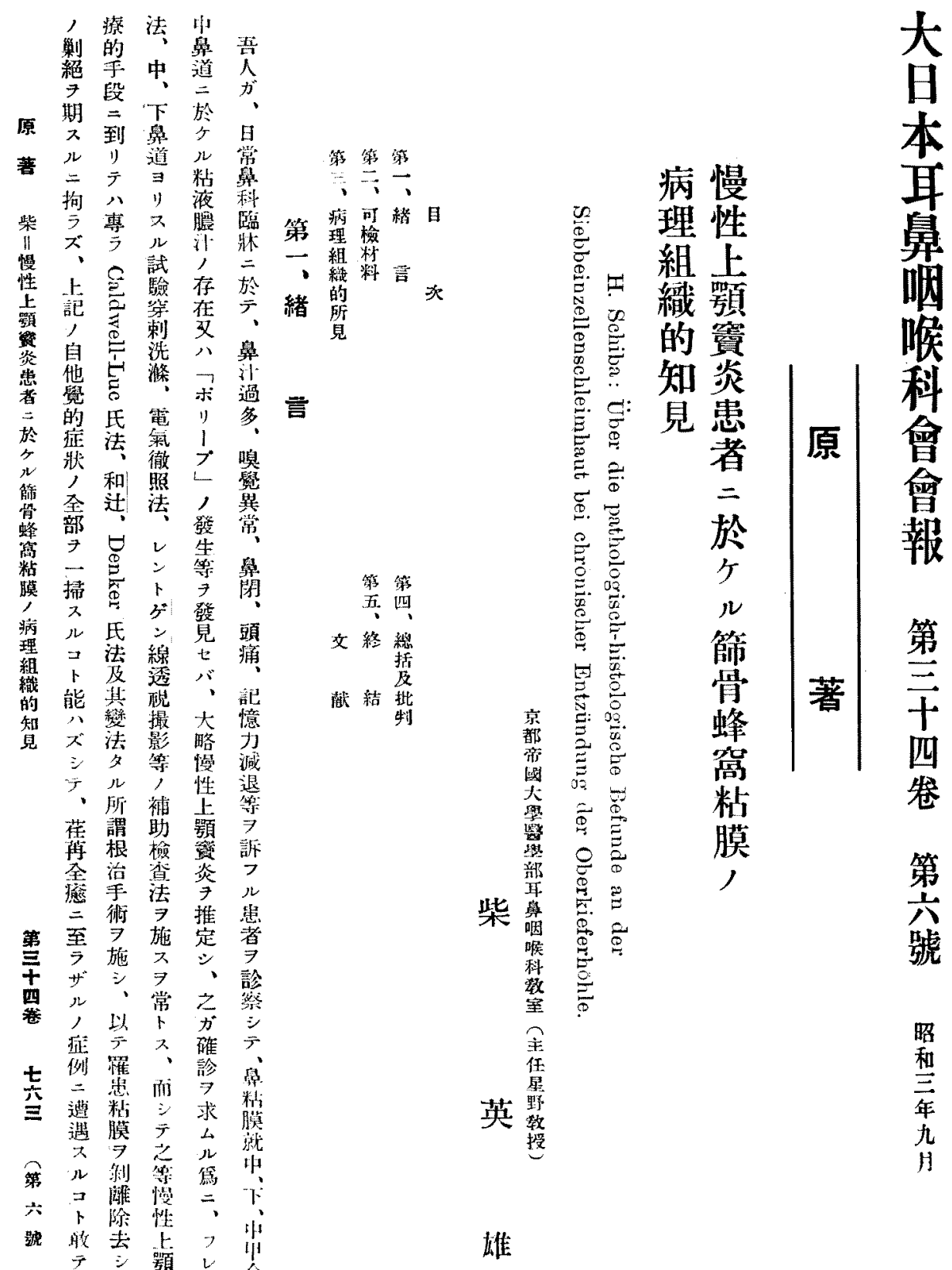




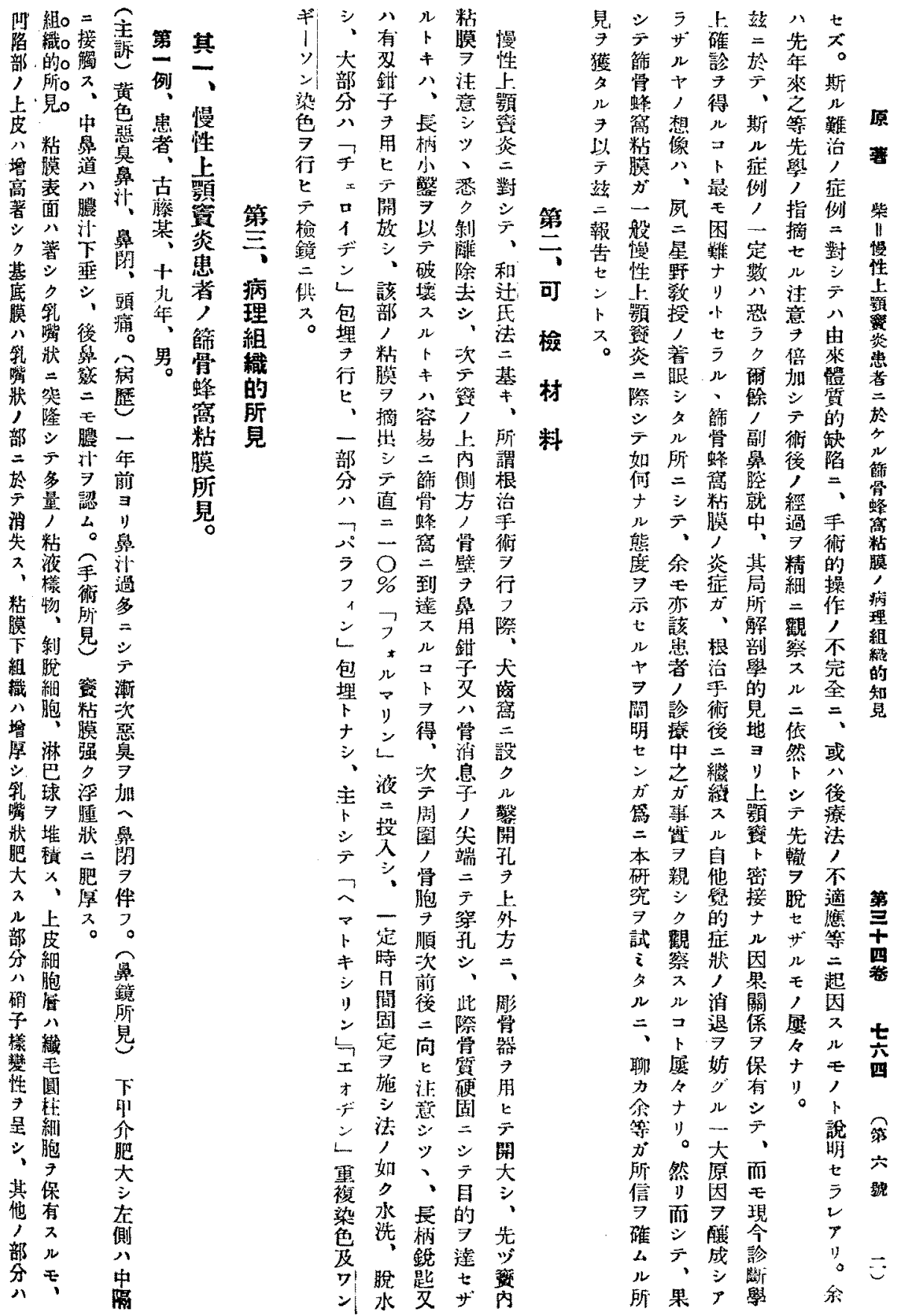




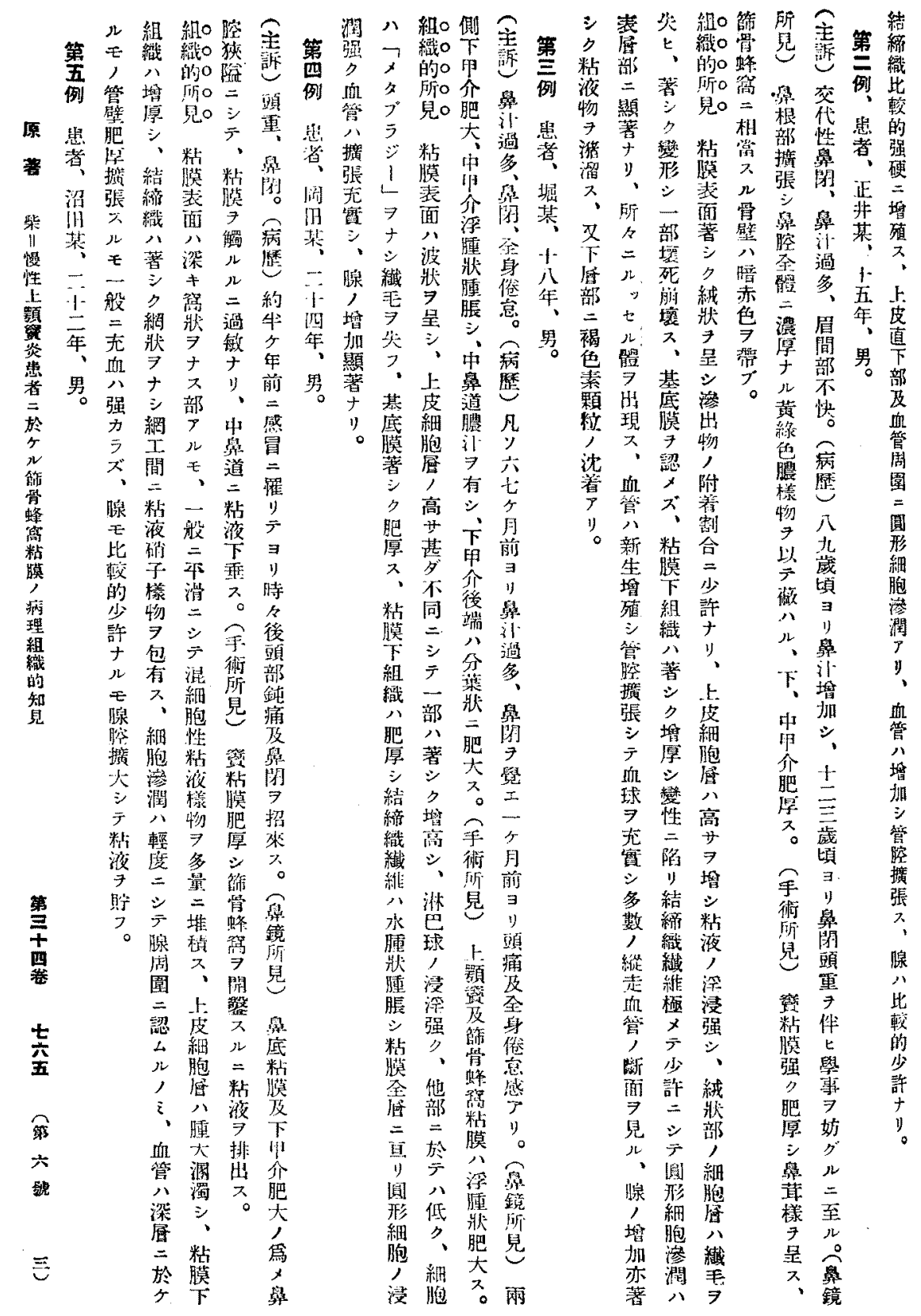




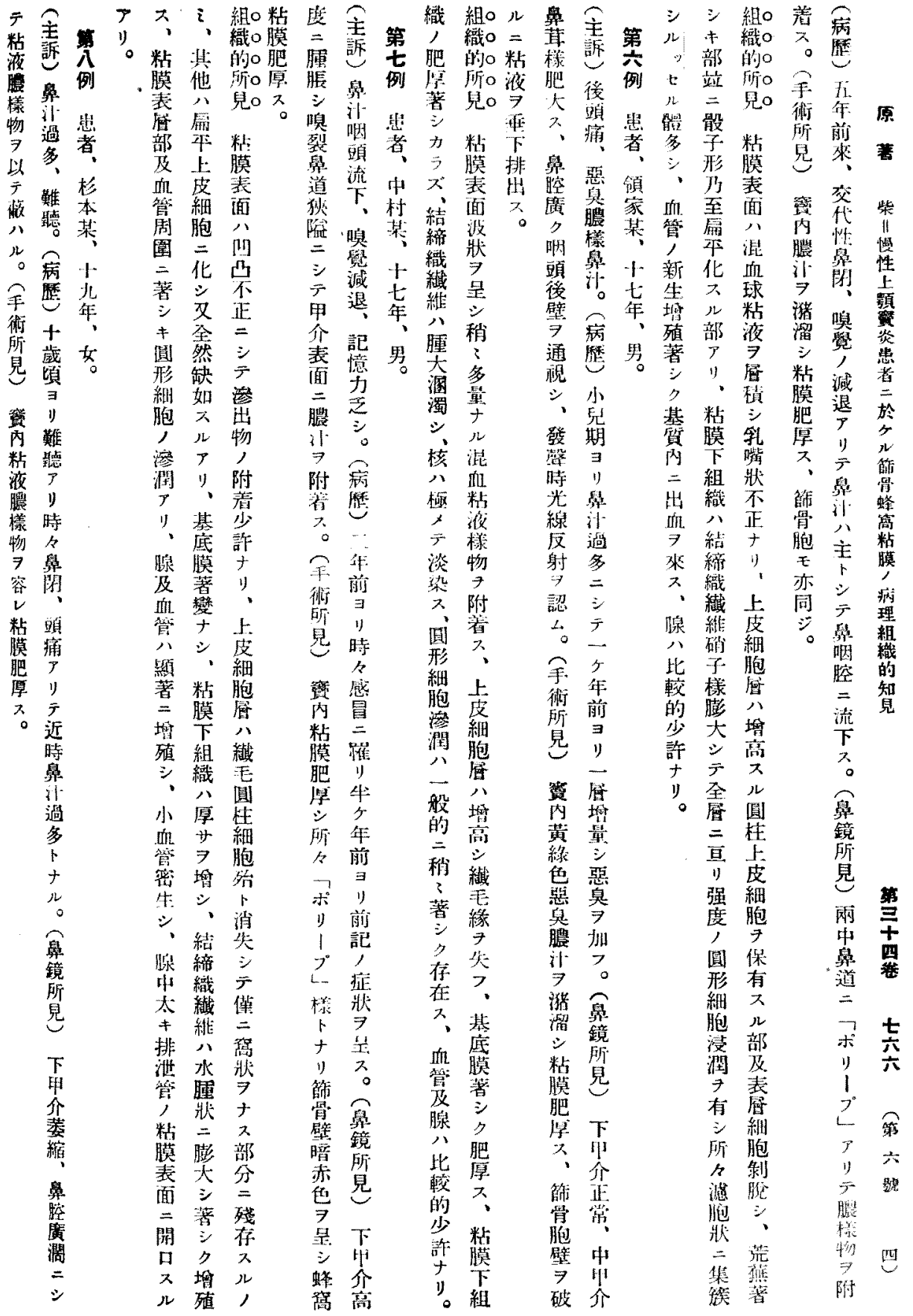


原

整

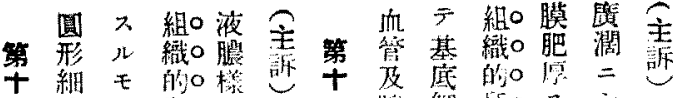

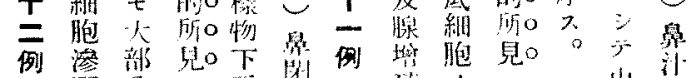

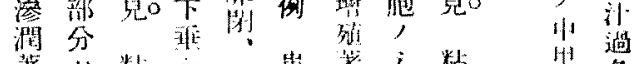

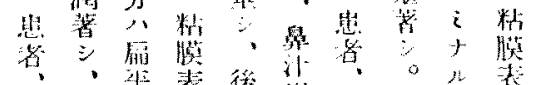

装

.

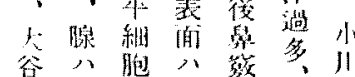

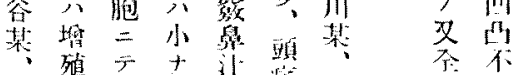

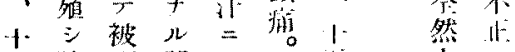

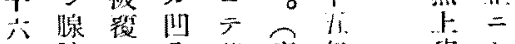

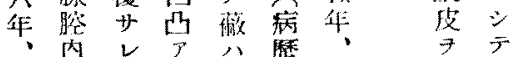

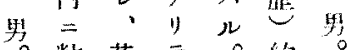

。䊀基示。䄪

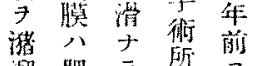

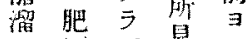

、、装

血 $テ$ 数 䇠

管緗液肉 $\vec{T}$

八胞楼粘

玩㙁, 物膜治
液底些手等

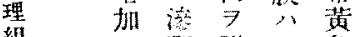

七濯附

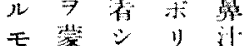

新台白

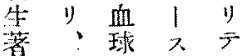

粘及上鼠

力膜剩卜䦌

亏下㓍 + 及

ズ組上り頍

織皮萌痛

第 秥胞\%, 件

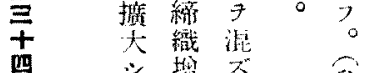

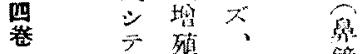

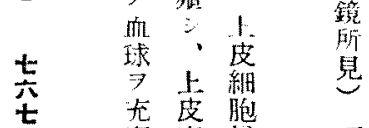

萑

少

躆

五
缺 粘

如

稀附

唃素

$\begin{array}{ll}\lambda & y \\ \lambda & \text { is }\end{array}$

$7 \quad \bar{\gamma}$

1) 緗邀

粘成衔

管分 筧

組 点

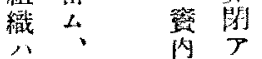

塯上膿り。

厚皮新的

粘胞容 痛

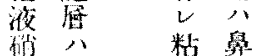

于四膜根

權杜 八部

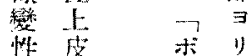

= 䋊 y 前

陷胞 I 颙

1) 7 7 部

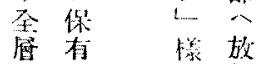

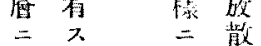

i. n 肥

昰分

形少妵鏡

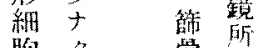

胞”、管鼠

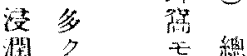

$\rightarrow$, 篦泉

有制朖道

シ胎 翻
モ 組 組。童 主 基 組。

$千$ 腔八的。柡挀杂膜的。

例摭整留二二鼻例消所。 头 胃。

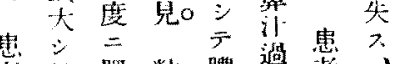

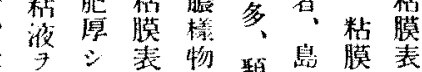

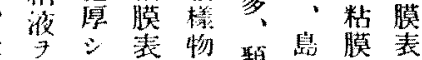

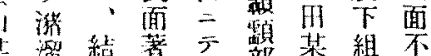

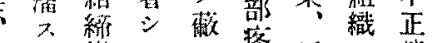

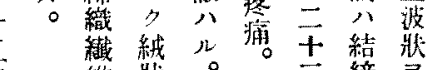

維牀。三䋨

和今 房年織与

础ナ手歷、睤 シ

子シ術已男殖粘

棈粘所六。シ 㳔

腫液見年棈

天漛前肥物

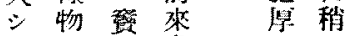

$\bar{\gamma}$, 队鼻到?

古附搬就必多

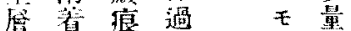

二多榡多高二

百方組二度堆

リ・織 シ t棈

テ上传 テ ラス、

稍皮入筆希䄳

高胞肯前細毛

度蜜壁手胞圆

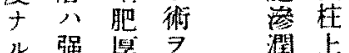

㨽夕シ受公皮

形粘篡 方音

紐波聜夕讯以

胞性塽儿的テ

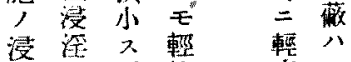

深售。怢度

$>$ 眥 $t=N$

1) 4 ズ 劉王

1) 114 , 細

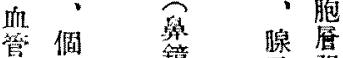

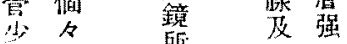

+ 哲 血

～緗皃管增

胞手弯高

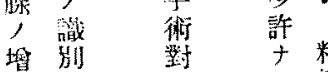

学困自液

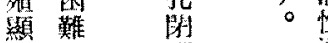

落 + 锰

$=$ !

齐粘 中

何嵘留 


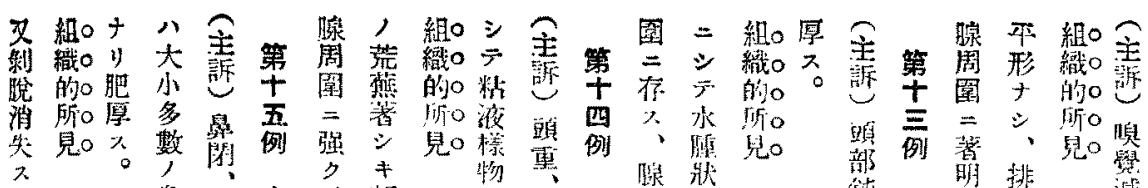

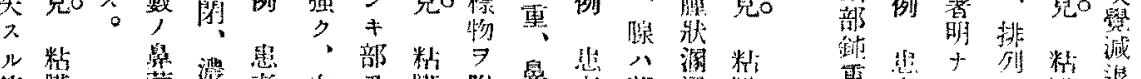

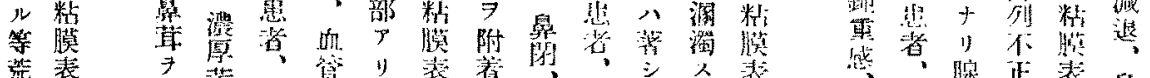

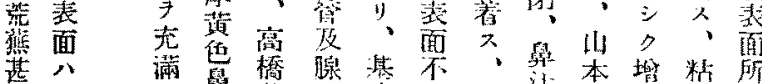

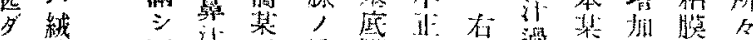

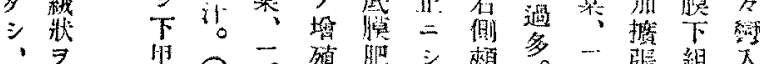

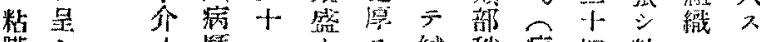

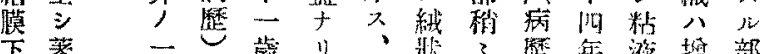

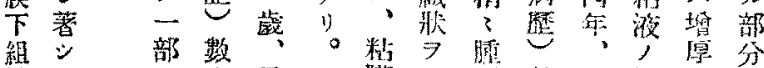

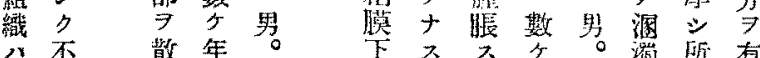

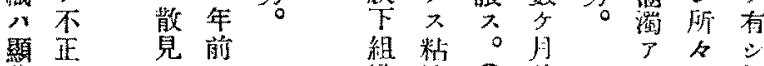

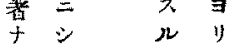

2 $\bar{\gamma}$, 䛒

維数附

胞 液

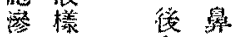

调物率

$\Rightarrow$ 多效 通

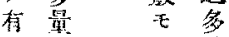

示车

絾烓 市

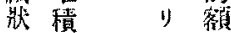

部 $、 1 \frac{1}{2}$

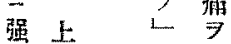

シ友 二拁

、䋖 㷊

又胞 蔽 ま

可磨 以近

伐窩

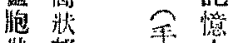

就胡街

二集有所 減

镱

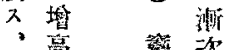

表漂经次

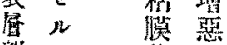

部を著 ス

八场米。

子能管界

檬 $=$ 年

性管

$\Rightarrow$ 川

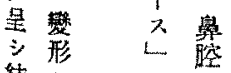

钴さト间
緋 液 击

肥附衔少

量 畋鼠

多鬼瞅

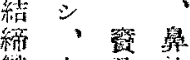

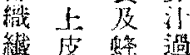

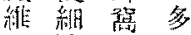

八枹 $;=$

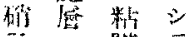

于 $八$ 㬴

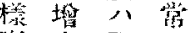

勘高强二

大 $シ 2$ 感

* 强棌置

模》䞔=

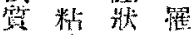

液肥 ᄂ

福捗大山

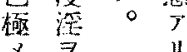

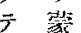

10 14 㩆

兵り、解

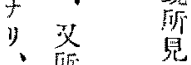

[बis

形 1

納友

䄈

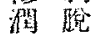

, シ 一

表薄縕年

龊肥盵

\section{1) 新}

, 于 胞

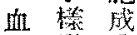

管学

亦 墙 7

foll 降

壵り

整 赫 罚

大战液

- 斯程

$\therefore$ 桝
粠

却觜

哭》。

7
+

模䋨

$=\quad$ 胞

焉背

就眐

非

格

等 7

等 位

方

亏. 脂

\#能

ル敢

飞核

脙

政 翌

栬 不

影主

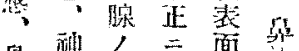

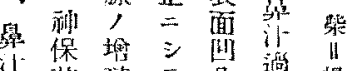

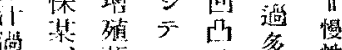
多

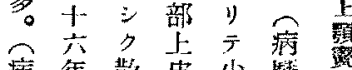

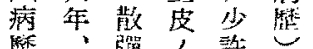

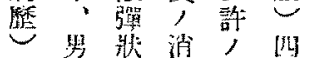
䄪。二起 粘年

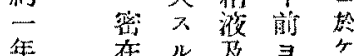
年在儿疋寻尔

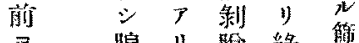

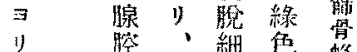

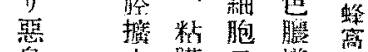

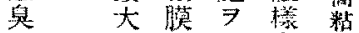
$3 \quad 3 \%$ 矿 5 㹂

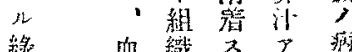

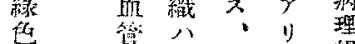

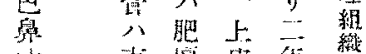

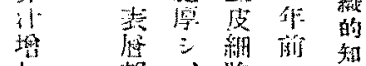

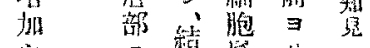

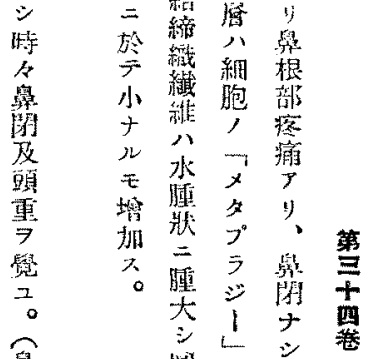

舀

蹨

胃

繁

倠

蝶

简

粘

櫒

共

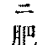

圆 柅 \%

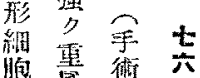

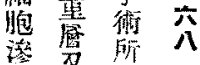

清少昆

八嫼

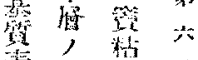

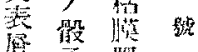

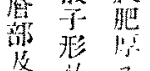

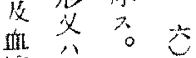

综, 后 


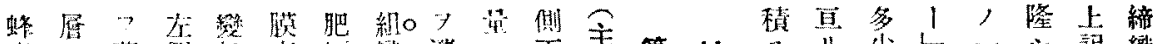

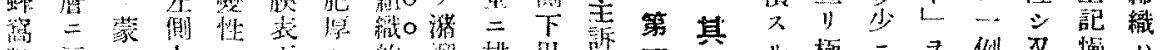

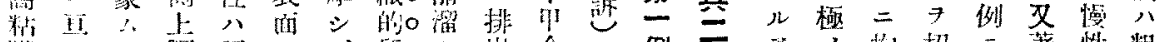

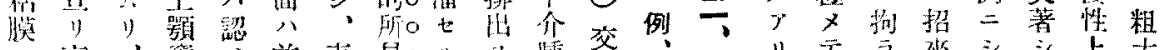

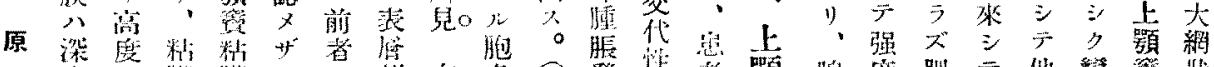

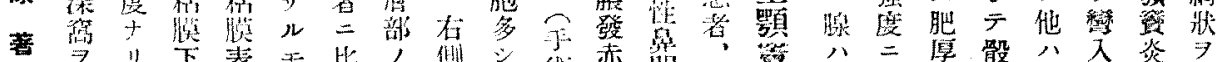

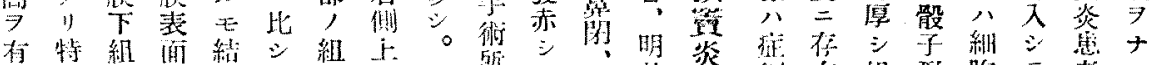
$*$
$\|$

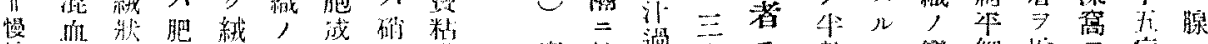

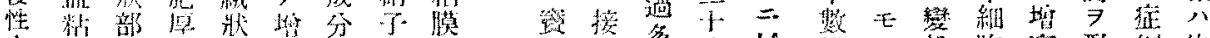

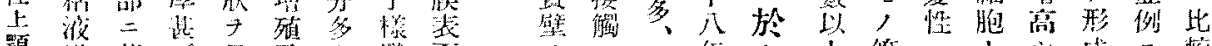

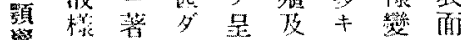

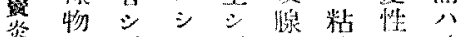

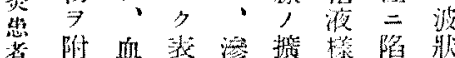

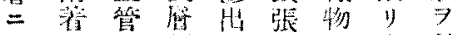

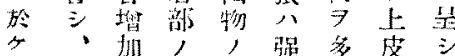

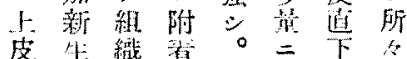
瓶

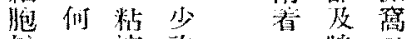
猪 $v$ 滩 許 八 E 破 +

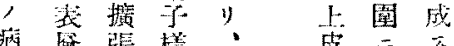

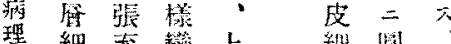

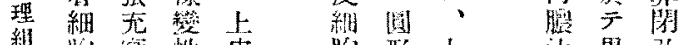

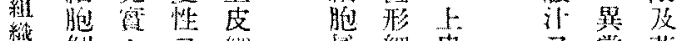

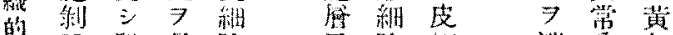

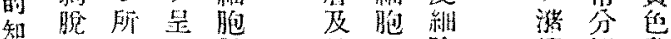

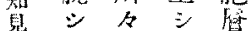
薄 猪 基 血 圝 故

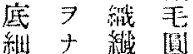
胞 双水胞 $\rightarrow$ 嫝

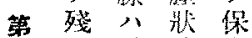

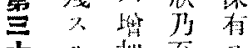

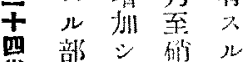

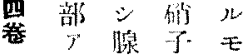

1) 住 㧼

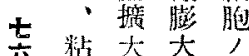

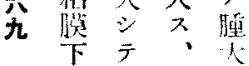

絸 䊀 洞

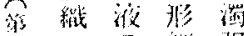

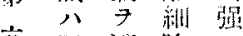

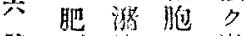

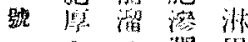

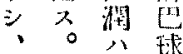

七 䊁 间 基 等 、䫄 粘, 脂 膜 磨 下 满心

种 7 舀

権 y,

放

正

ル In य.

留 䜣 袁

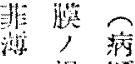

* 㶅

萿和

题 强 一

+ 4 站

) 1 औij

就 $\stackrel{1}{=}$

们於察

化公胞

八菇得

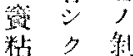

船 4 然

, Jा 敬

E $\vdots$

, 且 2

央撨 数

阔 陙 5

$\begin{array}{lll}\text { 小 } & x & 0\end{array}$

二间 粠

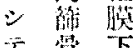

基 䗋 組

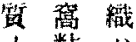

$*$ 物

膜 解

八 $x$

浮 ズ 䭝

霾、西

哭下 部

$=$ 留

㜆湴

$14 \Rightarrow$ Wij

大哿 額

- 剌胡

䈣 $*$

筜

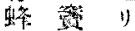

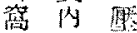

$7 \quad 7$ 重

整 筑

闻潗

又的

$=0$

网 䊉

仳脿

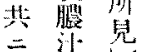

粠中

液 等 两

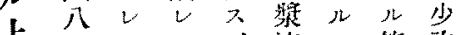

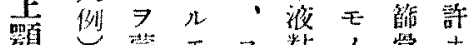

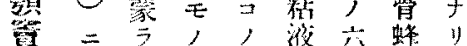

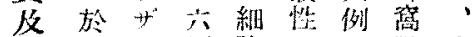

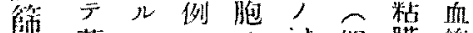

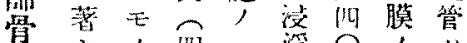

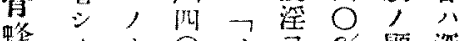

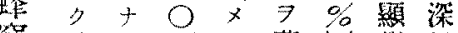

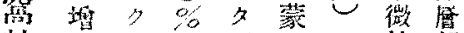
粘加、、ブム二鏡部

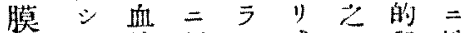

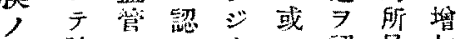
縕眿,

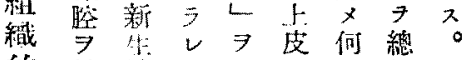
的筑场、呈 $\Rightarrow \nu$ 括

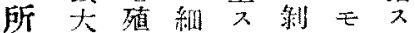

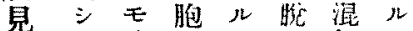

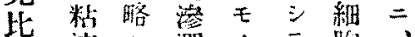

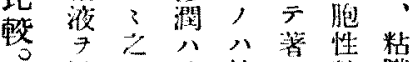

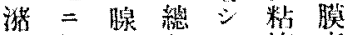

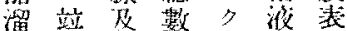

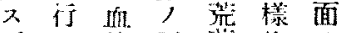
称 $三$ 獾物,

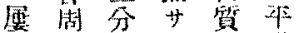
令 基 二 二灭附

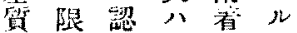
队间 $x$ 固 七 $=$ 入 有り H, ル, ○

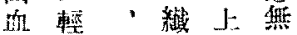

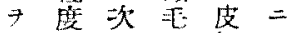
北 + = 圆 維 $三$ * 4 粘 枇胞

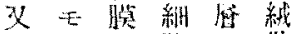
八，下胞，比

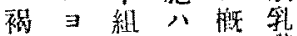

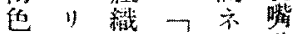

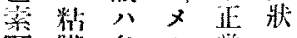

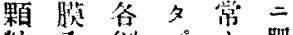
斩全例 $\rightarrow+$ 怔 , 曆 共 


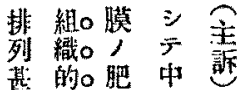

多所。愿 19

不兒。著介鼠

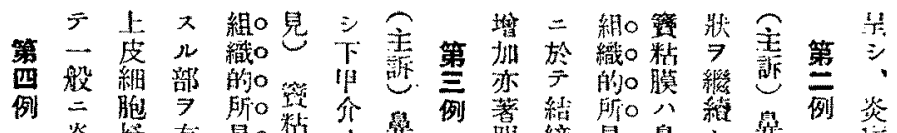

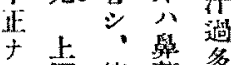

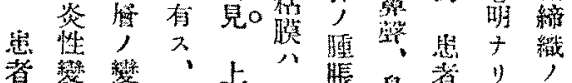

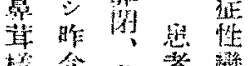

原

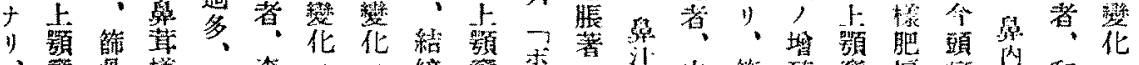

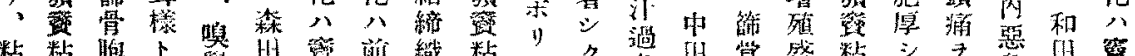

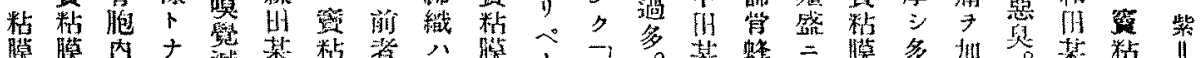

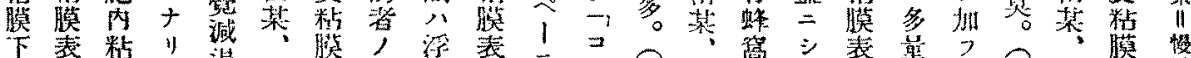

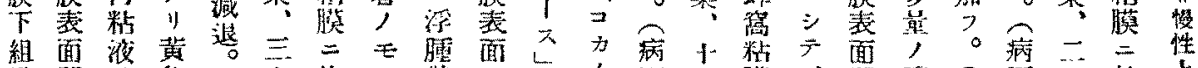

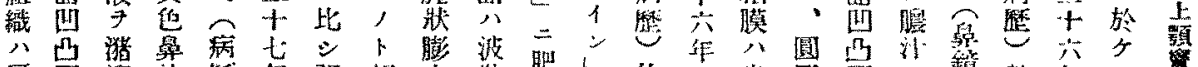

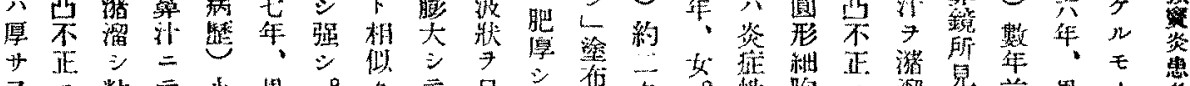

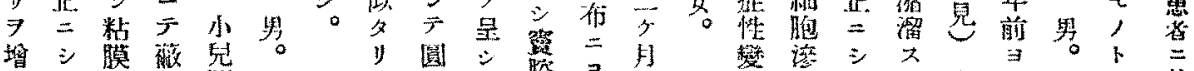

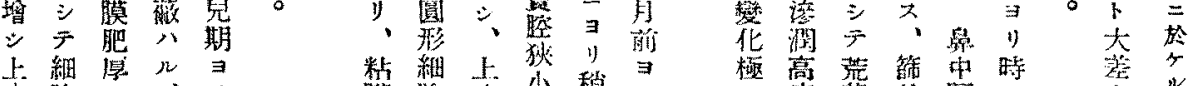

上. 絸 厚必州

皮胞息、叫

㨁成。中舅

下分學 沙

部 通多

位混 =

血 $x^{2}$ 整 两

管、粘背年

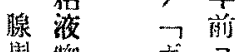

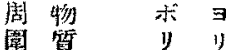

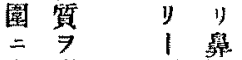

高附 ブ䁡

度者视,

儿、有

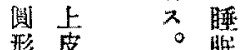

維細 7

睹背洐坊

潤原䓄只

$\Rightarrow$ 大見

有部斗

瓜算了

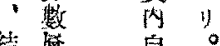

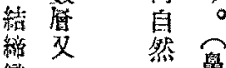

緎只品鼻

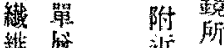

緋, 些是

确厤 数

击正储下

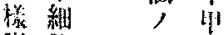

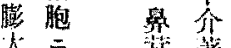

化 $\quad$ 些

細 有乡

細、方䡠

签胞度小稍》

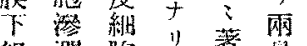

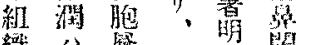

裁

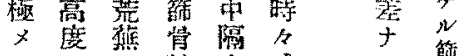

$\bar{z}=;$ 䊀左感節

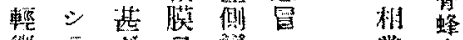

徽 ブ

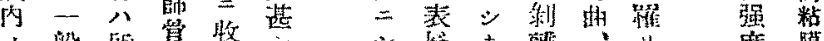

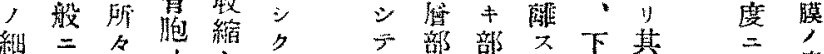

胞强䣙

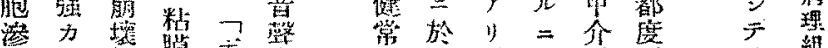

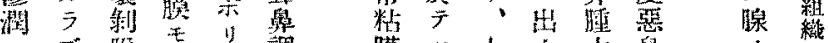

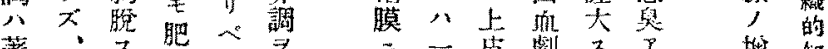

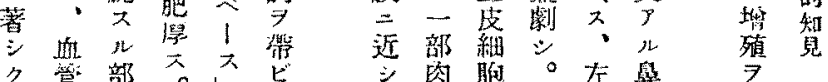

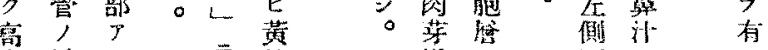

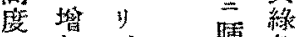

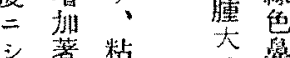

テ齐䑏不

多 + 定多

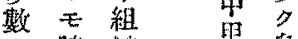

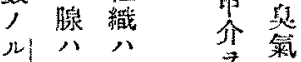

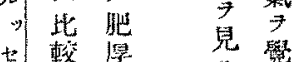

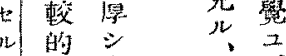

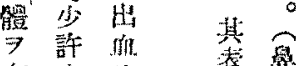

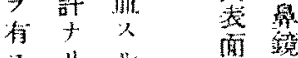

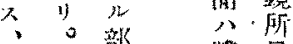

南籍分腿胃

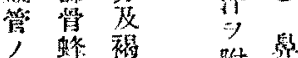

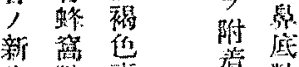

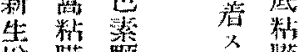

枆获颗 。颃

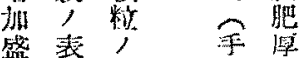

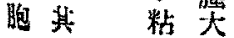

二面沈衛

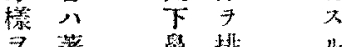

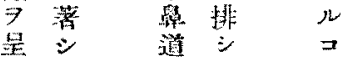

ス 試察下

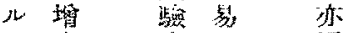

7 高绮 $=$ 同

y音制治落。

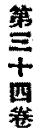

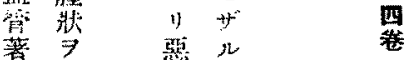

星 要 $\Rightarrow$

$t$
$t$

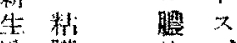

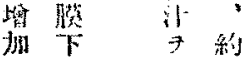

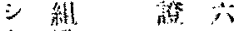

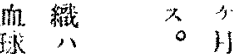

S?

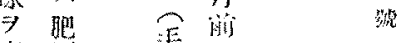

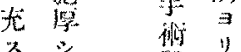

$\because$ T 留同

腺展思棬 


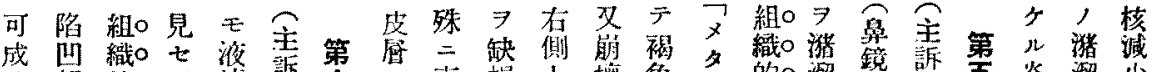

成 部織。七

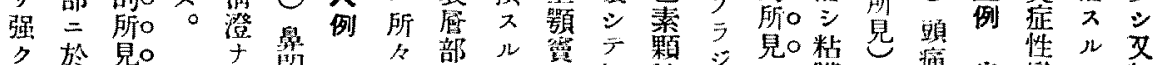

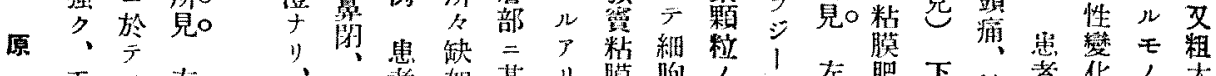

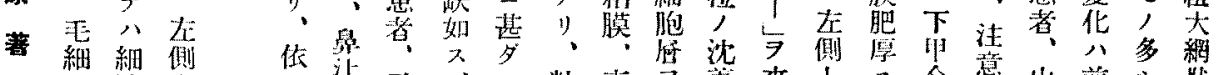

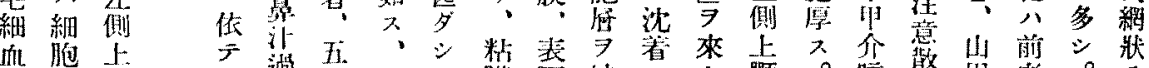

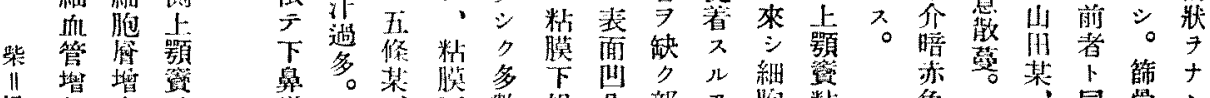

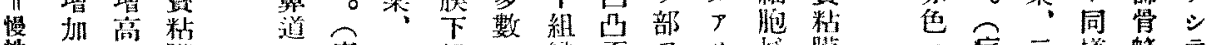

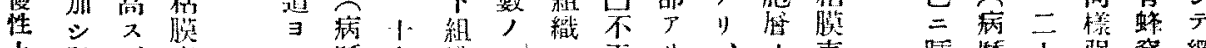

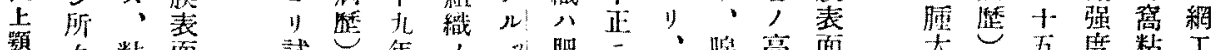

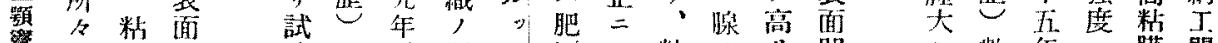

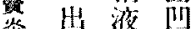

桖等

措 組不

$=$ 、織

於腺公二

父著 シ

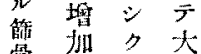

露 扣吕萌小

简腺瑟,

粘 管 シ 竘

膜撞矿 大

, 大子 7

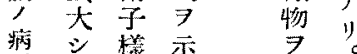

理 テ 粼

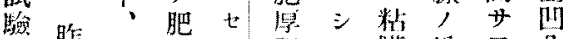

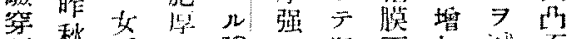

刺秋。强螑多混下扣娍不

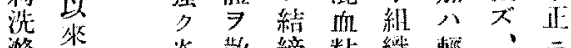

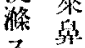

炎散締粘織签: 二

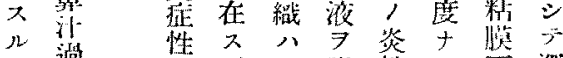

$=$ 逗

相: 一附性”下梁

㩽 多

液

化血部㧌戀、組鼠

八管憵

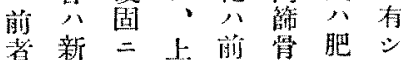

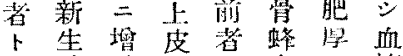

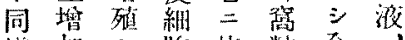

䋘 細性占明鼻

的胞二货范鏡

知成傾緗

見 分胞

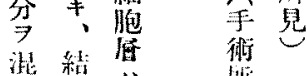

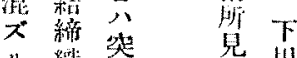

饿篗

大細部

核然

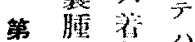

寻弯形不基

署成良思

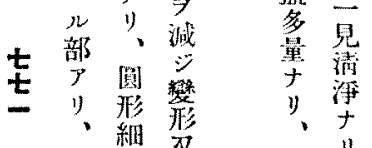

同胞又䇴!

第簿港会党鼻

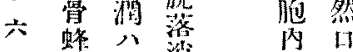

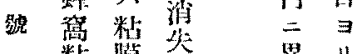

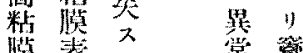

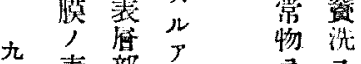

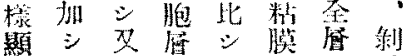

著腺基公秒表三脫

†亦筫水 8 面王上

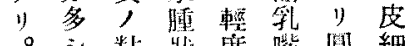

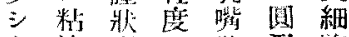

㸃淮睃子状形胞

所推大儿腿緗

今 子

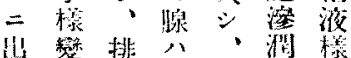

血性列極上湿物

x二不 $x$ 度,

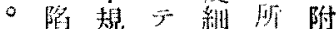

问 2 則絮胞々看

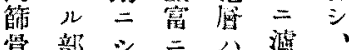

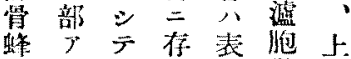

窝り、淋住愿牀皮

粘、巴公公二 緗

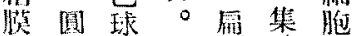

表形, 4槕

面細遊

著胞落

下小列

桨

シ 政 作 二 膜 間

テ年江表二

中 前是

泉 $\exists$ ・著子

蓬り腺 シ 㧼

二鼻八刀物

異㜀著愁子

管及包

物 頙 シ 不有

$\Rightarrow$ 重增正

罗 $\supset$ 加 $=ル$

ス 1 ス

試屚占”,

然的

第 醫

剌 治

$=\Rightarrow$

$\exists$ 受

装

線 $\overrightarrow{5}$

出覀

管

$+\quad \exists$

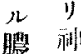

檫 䌯

物 衰

$\Rightarrow$ 弱

證

明

又爲

○肉

皮 血

細 管

胞 八

屡著

墦 另

高管

䄉一文骰烦三

手 科

热

淋 シ

巴

悠般所打

的分形多

所 治

見 蝗

球 们

是 $=$ 尹 数 胞

' 2

浸委

䒱

么 張

!)

上存占呈

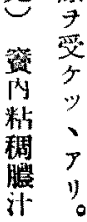

基 球

底 7

傿

厚

入 脘

粘 亦

䑏 增

㱞

樴 テ

二 粘 


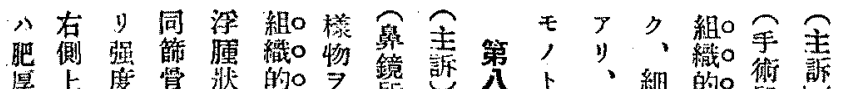

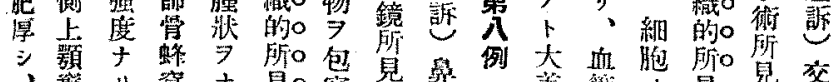

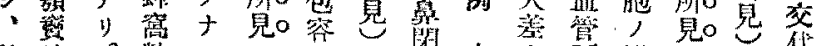

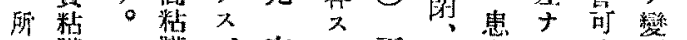

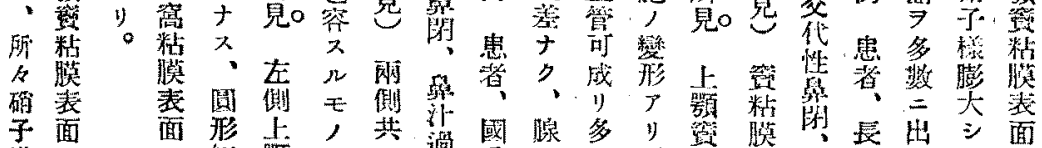

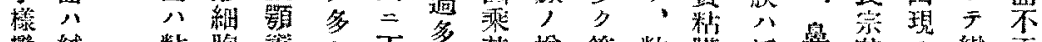

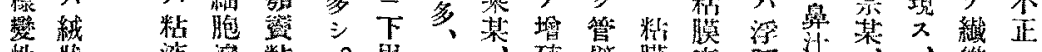

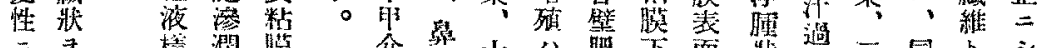

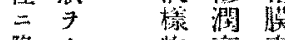

陷十物高塬

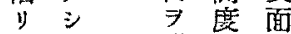
緒細附三， 縛胞装三留

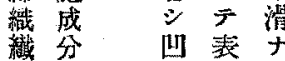
維寻喿歷

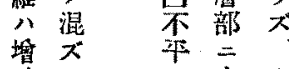

殖

シ 粘

F 液

水榢粘八大

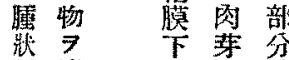

堙附 組 榡 消

大着䇅 $尹$ 翟

シ シ 公呈

粘上愿儿部

膜皮方厂分

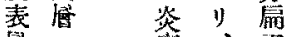

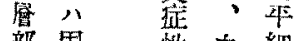

部固性 血 細

二有杪管胞

於, 化筧 7

テ組公殖以

圆胞璐 $心$ テ

形形管蔽

絧

膜管蔽

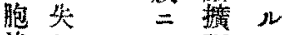

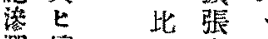

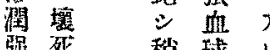

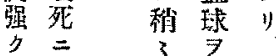

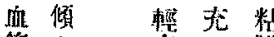

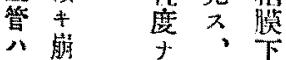

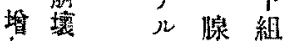

拁 $九 久$ 織

江維比八

管 $y$ 随較肥

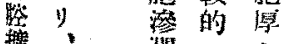

蕒

張

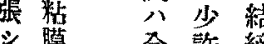

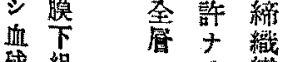

球 組

今. 模 亘。維

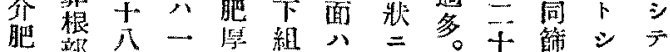

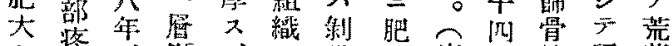

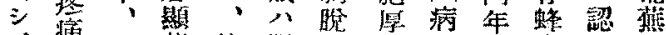
中男萫篗肥占 政

道 整

计 三

$\exists$ 叫

罢年

○

手鹳

兒罯

琶脃

粘 舆

膜 计

八多

菙量

權 シ

肥 約

榢 -

シ ケ

剩 $\mathrm{F}$

踓 前

管 $\exists$

舅

》、根

、部

左 疼

揑 演

蜂 及

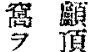

開 部

放 蟹

ス

ル 憼

$=T$

粘

リ䗋程是約

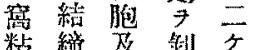

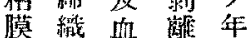

表 球 三 前

晌增 $尹 \vec{\gamma} \exists$

改殖混籍少

上强 元除鼠

茎名必简

展圆数

人形菉管计

工細物吕過

的胞 $7 \exists$ 多

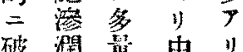

破潤量中鼠。

* 粘堆遵鼠

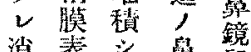

消袁

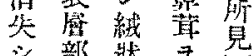

留 $\Rightarrow$ 基

其腺呈二下

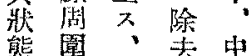

不 $=$ 上 $\mathrm{x}$

捧存菠儿芥

ナシ細 7 烡

1)、胞得 $=$

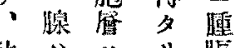

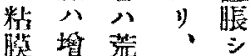

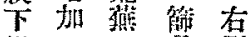

組シ 管 鼬

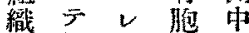

, 散脽粘鼠

所彈落膜道

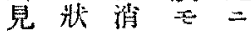

八二肤鼠

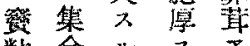

粘合儿ス

膜部・”。
㫤

度

維 籍

胞 II

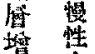

商

ㄱ.

藏

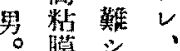

所, 上

䙿永皮

公增 胞

前 殖

者芯埶

太敗

大 大脫

ク $シ$

上

皮緗部

展胞多

, 成 シ

督分粘

北 7 愺

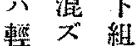

† 几 織

絸 維 肥

胞素愿

洷粘

八橉全。滲

一 物 膚

量窟亘

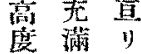

ナ

。基 組

䓄胞

度

血 閵

、怔

小ナ

小血管少 


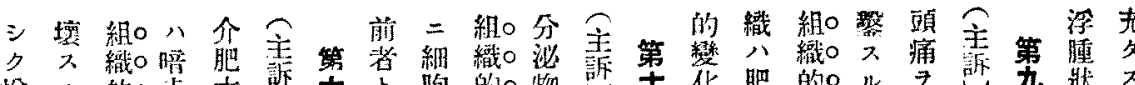

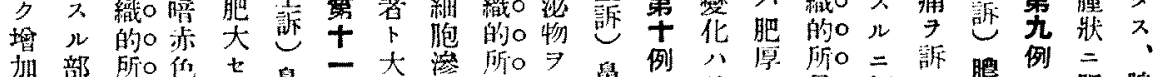

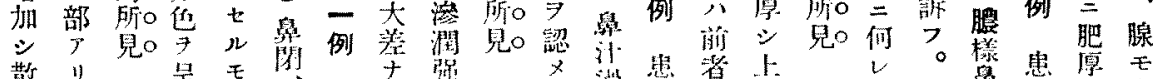

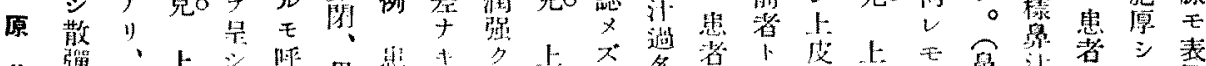

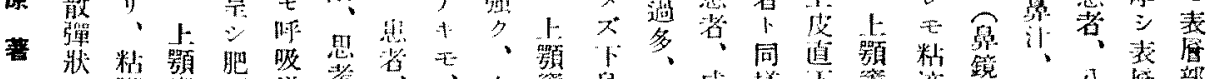

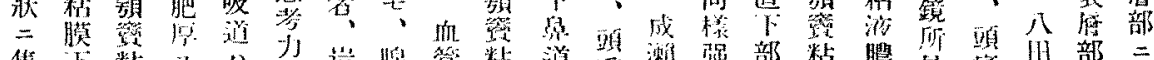

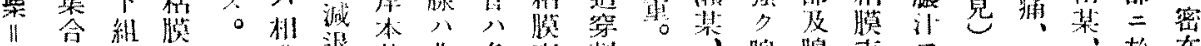

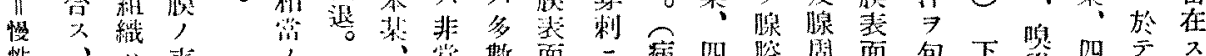

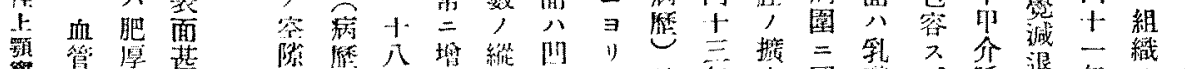

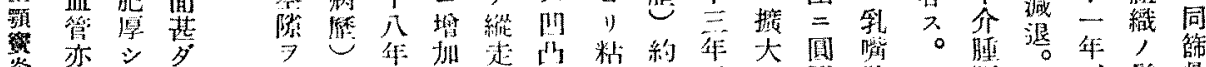

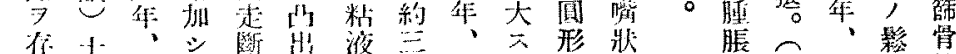

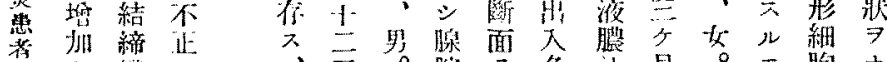
$\Rightarrow シ$ 織 $=$ 三丨腔 7 多 月月。胞

於管塯 シ

ク腔殖テ

中蔵

推留

大都入八》

先落

篦名 シ

鼠

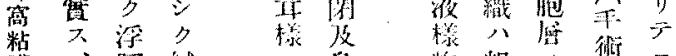

淮䋨胞

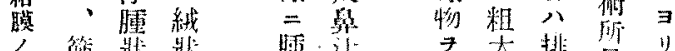

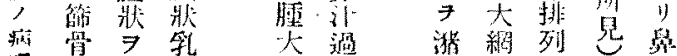

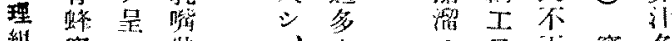

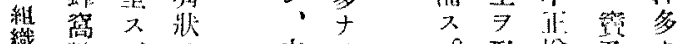

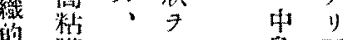

的膜粘 + 岳两

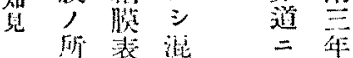

星感血 粘前

八部膗淮 $\exists$

前殊 计㧼 ”

诸 $=\rightarrow$ 物

5 乳 附 7 种

相蝔署。附的

匹槑 ス落作

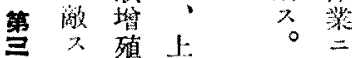

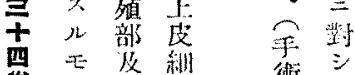

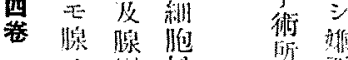

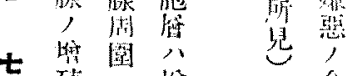

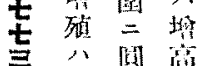

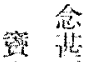

一 形 $~$

阶

度 紸 緗

数

第 萤 脂胞

形墔范名

成 高穊䫒

确又粘厂

子虔膜

㯃平公市

物化浮不

包心跃于

有綀二”

入胞堽

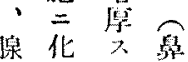

八ス。籍

稌几南

少部見

空腚滃排

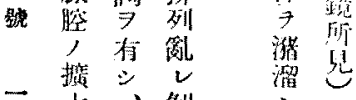

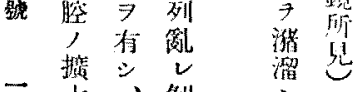

液震

二大腺胜粉下 ル著符

谴印

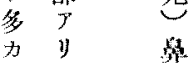

亏、彩

希粹腹

第

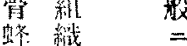

品 憡

粘热潤

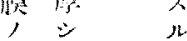

䙿虔異

見㸃異

\section{, 滲 シ}

多潤 深

少顯郮

䈏 7

1) 鿊

Int 䏚

管

八皮

小级

口 粘

聇 淮

血 孚

管 附

泌者

在

文

叒度

血L 緗

七 胞

几 据

部

》淋

膦球

八,

童猔

$\pm 7$

方僢

年是

籍

省 场

等隽

满

膜 粘

炎 瞙

租
窉罗踈䗇

總厢。十浻

舅 儿粘

道十部膜

中在 》病

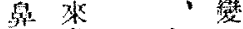

消采細公

膘㜀

胞 $\overrightarrow{-}$

提紧济般

物 $y^{\prime}$ 潤二

$\Rightarrow$ 茫前

淽過虽者

夕多旗二

シ $Y=$ 比

数 リ 亘

凮嘍 年 整

鼻 前 $t=$

草铔少 シ

7 两强

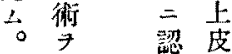

受复細

手多胞

街鼻店

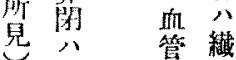

㹂算

窥诚腺圆

数 三八柱

膜夕比 細

八ル 較胞

嶨 $\mathrm{E}$ 的

菲睤少具

㩐沁許偕

肥八t”。

桨焦 ”。

然

管 量

脽

組 
從頻 $\bigcirc$, 来 锱 雨 數

來 \& $\%$ 成炎來 $=$ -

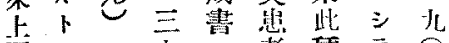

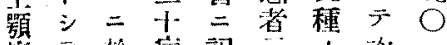

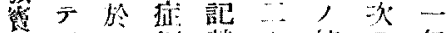
翡同

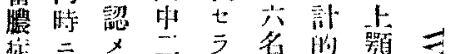

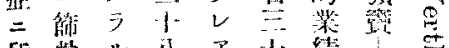
所綮儿 八

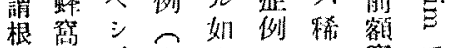
治炎、北々 $=$ 筑 手 7 素 $三$ 期 就

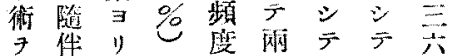
抽 $シ$ 余 7 二瓶特更 0 ᄀ, 鼠於膜二二例 ルル可スデだ) 七十检”他声顎二在

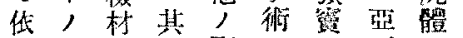
然一料丙副的ト壬二 端

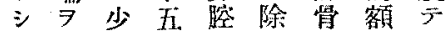

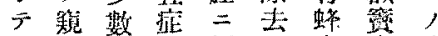

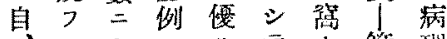

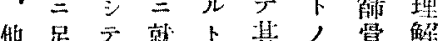
覺㠿之テモ材作蛒剖 的 今 $\Rightarrow$ 雨劣料合离的 拉 + 以粘亏 5 炎, 統 狀モ $\Rightarrow, \cdots, 儿$ 理二位二 存卜船篗, 縕就 7 指

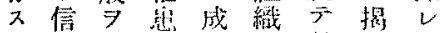

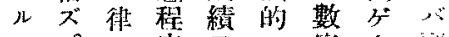
二 0 度 $\Rightarrow=$ 等

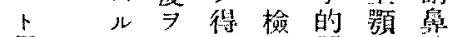

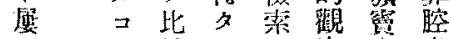

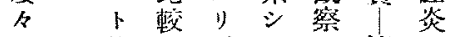
7 能不、䈔了

分ル則ル遂骨修

八 $\forall^{\circ}=$ 于所年䗋合

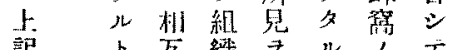
記 互織 $7 ル$, 八 八的标文伷發 如 言變二合藏 合病 万人, 明 $九 7$ 性七

频、滕滕儿探炎儿

繁 慢 ボ 二 ス八元

$=$ 性 $一$ 网晍

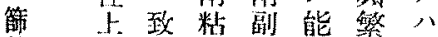

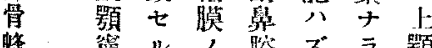

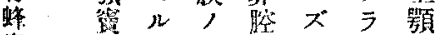

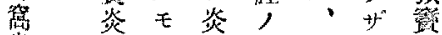

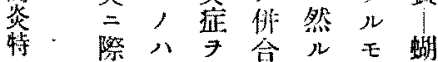

$=$ シ 過合性二, 蚮

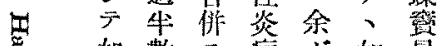

如數 $大$ 症

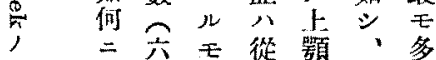

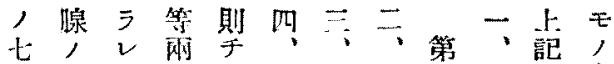

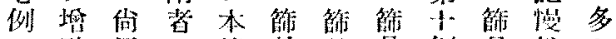

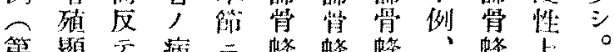

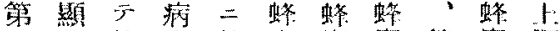

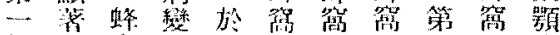

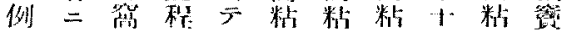

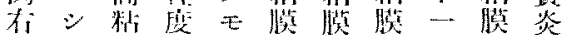

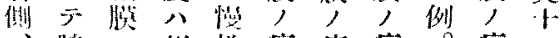

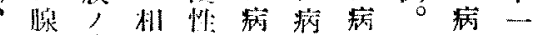

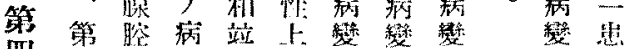

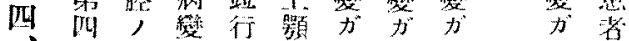

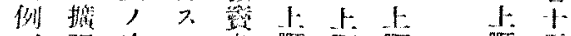

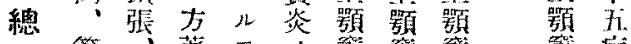

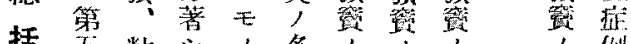
括开粘 $心$, 多, , , , 桝

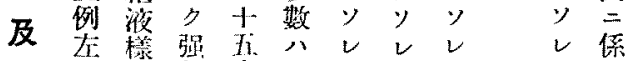

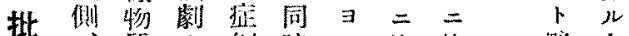
此算 + 例 時 $y$ 比比略 判第; $⿻$ 凹

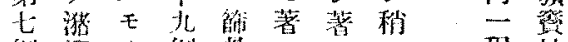

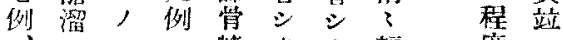
第 ス

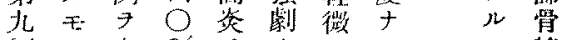
侧, $19 \%$ \% $\%$ E 蜂

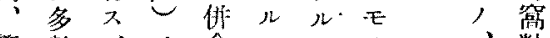

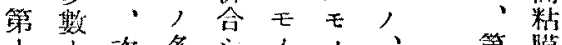
十十次多文，，、第腾 桝、、三 期 第 $\Rightarrow$ 唯 $y$ 話

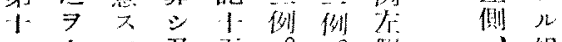

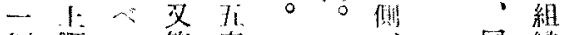

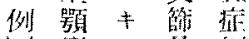
$\cup$ 籍 $=$ = 粹 蜂 所 於膜简十 万 劣 粘 回 圣ル組膜 例 拨 所維, 例見 $=$ 紡 , 1 在愁 約比儿, 明 位檕䐆稍力 數 $2,3=$ $\overparen{\Pi}$ 留 公献 $=$ 馀 $\%$ 若 $*$ 七明 $0=\bar{\sigma}, \quad$ $\Rightarrow$ 在 解 以U ル 17 背 例 7 1. 万峰 $几$ 得

间 㧔 第右的 分 俅 宕 侧 第 左第 7 例 较 第 第 喔 例 fi 证侧夕 俳 右儿 同 績 右 第 7 側 六 穆 (夘 括 ti 3 僛 ᄂ 第 $=x$ 例 妏 方粘 $\begin{array}{ll}\mathrm{b} & 1\end{array}$ 伶少页

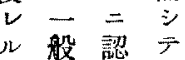
千 = 叉文
整

修 
筫 入方久

， $=儿$

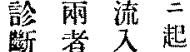

